\title{
Epidural Steroid Along With Tramadol For low Back Pain With Sciatica.(Original Article)
}

\author{
Dr Vasudha jadhav ${ }^{1}$ Dr Ranjeetsinha jadhav ${ }^{2}$ Dr Prashant Lomate ${ }^{3}$
}

\begin{abstract}
Epidural steroid injection has equally good results in acuteCases than chronic cases .Duration of relief varied from $1 \mathrm{wk}$ to 4 months .Low back pain continues to be a leading cause of disability .It is thecommonest complain of most of the patients presenting to the pain clinicand orthopaedic out patient department. The cost to society and thepatient in the form of time lost at work ,compensation and treatment isstaggering.
\end{abstract}

Key words:- Epidural injection, metylprednisolone, Tramadol, xylocard

\section{INTRODUCTION}

It is estimated that about $80 \%$ population suffers from lowBackache at some time with annual prevalence of $18 \%$ and incidence of $15-20 \%$ (quebec Task Force on spinal Disorders)low back pain can be self limitingbut $1 \%$ patient remain chronically disabled and stay off work for more than twoyears. The spinal nerves emerge from the spinal cord ; they travel laterally 1-2 cmbefore they exit the spine. It is at this exit (intervertebral foramen) that thesenerves are most likely compressed or 'pinched' by either a herniated disc orbony spurs ,narrowing of the exit secondary to the calcification and decreasedspacing between the vertebrae . This pressure on the spinal nerves causesinflammation and pain . the pain could affect the back alone or can irradatiate

to the legs, which is known as sciatica.various surgical treatments require high coof majorsurgery . All kinds of treatment including bedrest, physiotherapy, manipulations, traction, has conservative treatments for these conditionsinclude analgesics, antiinflamatory drugs, physical therapy and epiduralsteroid injections other therapies are heat, acupuncture ,massage and stressst, skill and all riskEpidural steroid injections are most effective in the presence of nerve rootcompression. Epidural steroid injection are safe and conservative. Methodoftreatment for chronic low back pain .They are quick, simple and economic. All hazards of spinal surgeries are avoided.The steroids are potent antiinflamatory agents and are injected nearaffected nerve roots . These injections arte effective when given in the first week of onset of pain .Usually 2-3 injections are required but patient can have relief with single injection also.This study was undertaken to evaluate whether there is any effect onaddition of midazolam to steroids used.

\section{MATERIAL AND METHODS}

Informedconsent was obtained from all 100 patients (ASA grade I and II who attendedorthopedic OPD and then were reffered to pain clinic . Patients with known cardiopulmonary /endocrine disorders were excluded from the study.Pain was assessed by VAS visual analogue scale, modified according to thepatients individual perception, in percentile. Straight leg raising test (SLR), lasegue's test were done prior to the epidural injections , after each suchinjections and during the follow ups. These epidural injections were given at

monthly intervals and the patients were given at monthly intervals and thepatients were followed in the 2nd, 6th

and16th weeks. The patients were divided into 2 groups on the basis of whether theyreceived methylprednisolone along with injection Tramadol by epidural route.Patients in group I received $2 \mathrm{ml}(80 \mathrm{mg})$ of methyl prednisolone and25mgmoftramadolwith $2 \% 2 \mathrm{ml}$ xylocard diluted in $15 \mathrm{ml}$ normal saline . Patients ingroup II received $2 \mathrm{ml}$ ofmethylprednisolone and $2 \mathrm{ml}$ xylocard diluted in $10 \mathrm{mlof}$ normal saline . Procedure was undertaken in orthopedic OT under allIaseptic precautions, epidural injection was given using $18 \mathrm{~g}$ needle in thesitting position. Vitals were monitored for 30 minutes in supine position .

Monitoring included pulse rate (PR) noninvasive blood pressure(NIBP), oxygen saturation (SPo2) and cardiac monitoring of lead II when required .Results were categorized into four groups as done by Berman et al (1984)1 intheir study - Excellent i.e complete relief of pain and other symptoms no need for further treatment . Good i.e complete or near complete relief of

pain with minimal work restriction: Fair i.e pain and other symptoms ofmoderately decreased intensity with moderate work restriction and poor i.eno relief, unable to work and requires further treatment .

Statistical analysis - Chi square test was used to compere data with discretevariables while C test was used to compere data continuous variables. A pvalue of ,0.05 was taken as statistically significant. All data were 
presented inpercentage or mean =/- S.D. (Standered deviation). The sample size requiredfor having power of $80 \%$ for fulfilling primary goal (i.e percentage of

effectiveness of epidural steroids for low back pain with sciatica ) of studywas 30, based on previous studies . we had taken 51 patients in each groupto obtain power of $>90 \%$

patients were followed in the 2 nd, 6th and16th weeks. The patients were divided into 2 groups on the basis of whether theyreceived methylprednisolone along with injection Tramadol by epidural route. Patients in group I received $2 \mathrm{ml}(80 \mathrm{mg})$ of methyl prednisolone and $25 \mathrm{mgm}$ of

tramadol with $2 \% 2 \mathrm{ml}$ xylocard diluted in $15 \mathrm{ml}$ normal saline . Patients ingroup II received $2 \mathrm{ml}$ of methyl prednisolone and $2 \mathrm{ml}$ xylocard diluted in $10 \mathrm{mlof}$ normal saline. Procedure was undertaken in orthopedic OT under allaseptic precautions, epidural injection was given using $18 \mathrm{~g}$ needle in the sitting position . Vitals were monitored for 30 minutes in supine position .

Monitoring included pulse rate (PR) noninvasive blood pressure(NIBP), oxygensaturation (SPo2) and cardiac monitoring of lead II when required .

\section{RESULTS}

Total 100 patients with age $20-75$ yrs of either sex were includedin study large number of patients were in 30-50 yrs of age range. Meanage of patient was 45.3+/- 13.1, there was no significant difference in themean age and sex of the patients between the two groups (p.0.05). heavyworkers labourers were $29.1 \%$ while others were sedentary workersDuration no . of patients Percentage

TABLE

\begin{tabular}{|l|l|l|l|}
\hline Duration & No of patients & percentage & \\
\hline Acute & 22 & $21.4 \%$ & \\
\hline Chronic & 78 & $78.6 \%$ & \\
\hline Total & 100 & 100 & \\
\hline
\end{tabular}

Table- Results as per pain relief

\begin{tabular}{|l|l|l|l|}
\hline Results & V.A.S. SCORE & $\begin{array}{l}\text { Improvement of } \\
\text { pain }\end{array}$ & Number pf patients \\
\hline Excellent & $0.2-2.5$ & $75 \%$ & 20 \\
\hline Good & $2.5-5$ & $50-75 \%$ & 63 \\
\hline Fair & $5-7.5$ & $25-50 \%$ & 11 \\
\hline poor & $7.5-10$ & $<25 \%$ & 09 \\
\hline $\begin{array}{l}\text { Total Mean +/- } \\
\text { S.D.=60.3\%+/- } \\
20.1 \%\end{array}$ & & & \\
\hline
\end{tabular}

Table. Results as per duration of symptoms

\begin{tabular}{|l|l|l|}
\hline Results & Acute & Chronic \\
\hline Excellent & 9 & 11 \\
\hline Good & 11 & 50 \\
\hline Fair & 01 & 10 \\
\hline Poor & 01 & 07 \\
\hline Total & 22 & 81 \\
\hline
\end{tabular}

Table: complications

\begin{tabular}{|l|l|}
\hline No of complications & Over all \\
\hline Blood vessel puncture & 6 \\
\hline CSF & 2 \\
\hline Nausea & 2 \\
\hline Fall in BP & 0 \\
\hline Hiccups & 2 \\
\hline Weakness in lower limbs & 4 \\
\hline Increase in pain of sciatica & 8 \\
\hline Headache & 3 \\
\hline Local site pain & 4 \\
\hline Infection & - \\
\hline
\end{tabular}


Epidural Steroid along with Tramadol forlow back pain with sciatica

\begin{tabular}{|l|l|}
\hline Vasovagal attack & 2 \\
\hline Failure & 5 \\
\hline
\end{tabular}

Bilateral sciatica constituted $32 \%$ patients $28.16 \%$ of patients presented with neurological deficit in the form of sensory motor involvement Patients were grouped into two depending upon the duration symptoms(acute/chronic) .In acute cases duration of symptoms was less than threemonths. In chronic patients, duration of symptoms was more than 3 months .Acute group constituted $21.4 \%$ and chronic cases $78.6 \%$.

There was a Significant difference in the degree of improvement of sciaticain both groups and in both sides regarding straight leg raisng test as revealed by a $p$ value .The pain relief lasted more in group 1 with tramadol . out of 100 patients60 had good improvement of pain (50-75\%) 20 had excellent improvementand 11 had fair improvement .Mean improvement was $60.3 \%$ and theimprovement ranged from $40 \%-80 \%$. There was significant differences in results as per duration of symptoms(acute/chronic) we had few insignificant complications occurred in any

patient in our study

\section{DISCUSSION}

The use of steroid for low back pain with sciatica was startedby Cappio M (1951)2 The Suggested Mechanism of action of steroid is --

1. Breaking up of adhesions around the nerves (the adhesions cause oedema by obstruction of free flow of fluid in nerves and cause direct damage to the nerves by compression).

2. Probably accelerates healing of the irritated and inflammatory state of nerve roots and reduces oedema.

3. Inhibits phospholipase A2 and cycl-oxygenase enzyme(Lee ,et al 1998)3

Depomederol (methyl prednisolone) is the safest steroida agent when used epidurally and other agents which can be used are betamethasone acetate, dexamethasone and triacinolone . LBP can be classified into 5 principle catagories but ESI are indicated in spondylogenic and neurogenic back pain only physiotherapy, drugs may or may not work for every patient. Surgical treatment will need skilled surgeon and it also increases cost and risks.surgery may not be needed every time so ESI has been used many years

We aimed to study role of route in the final result . we had 46females and 54 males, a total of 100 patients in our series -- accordingto Gupta et al (1996)4, Commonest age group was between 30-40 years, while in our series , the commonest age group was 40-50years, followed by 30-40 and 50-60 years . 50 patients had suddenonset of symptoms where as 50 patients had gradual onset .cause ofsudden onset was most often lifting of heavy weight /bending. According to papagelopoulos et al 5, the most common cause for backpain with sciatica was disc herniation $(50 \%)$ in our series also the clinical diagnosis in most of the patients was disc herniation. As far as drug is concerned in our series $78.43 \%$ of patients in group1 had excellent to good results while it was $82.69 \%$ in group II hadfair results in $21.57 \%$ in group I and $17.3 \%$ in group II respectively. In the group I with Tramadol the analgesic effect was prolonged .According to Wallace et al6 and Sethi et al 7 lumber route is effective because it deposited the drug close to the site of lesion . so that route was chosen. ESI are effective in both acute and chronic cases of LBP .In our study 30 acute cases had excellent good results while $77.8 \%$ of chronic cases had good to excellent results.ESI are most effective during the acute phase of pain and inflammation according to V,Sing et al8Staehler 9 reported that an ESI can be very beneficial for a patient during an acute episode of back pain .According to report published by Manchikanti et al 10 ESI with orwithout local anaesthetic can provide pain relief in patients ofchronic back pain or sciatica .After successful injection the effect maylast from few months to several years.

\section{REFERENCES}

[1] Berman AT ,Garbarino JL ,FisherSM .Theeffectsofepiduralinjectionoflocal anaesthetics \& corticosteroids onpatientswithlumbosacralpain.ClinOrthop1984;188:14451.g2.CappioMSacralepiduraladministrationadm inistrationofhydrocortisoneintherapyoflumbagosciatica.Rheumatology1951;9:60.

[2] Lee HM , weenstein JW , Meller ST . The role of steroids and theireffects on phospholipase A2 . An animal model of radiculopathy.spine 1998;23:1191-96. 
[3] Gupta AK . Role of epidural medication in the treatment ofresistant low back pain . J Indian Med Assoc 1996 ;6: 224-6.

[4] 5 . Papagelopoulos PJ ,Pasalis MP , Petrou HG . Treatment oflumbosacral radicular pain with epidural steroid injections .Orthopedics 2001;24:145-9.

[5] 6. Wallace G, Solove GJ. Epidural steroid therapy for low back pain.Postgrad Med $1985 ; 78: 213-5$.

[6] 7 . Sethi N , sood J ,Kumar VP . Management of chronic low backacheDue to prolapsed intervertebral disk by lumber vs caudal epiduralmedication Ind Pain 2003;17:27-31.

[7] 8. Singh V, Manchikanti L, Role of caudal epidural steroid in themanagement of low back pain . Pain Phys 2002;5:133-48.

[8] 9. Staehlr R . lumber epidural steroid injection for low back andsciatica .July 17,2007. www.spine health .com.

[9] 10 .Manchikanti L, Cash KA ,Mc Manus CD, et al. Preliminary results ofa randomized, equivalence trial of fluoroscopic caudal epiduralinjection in managing chronic low back pain .Pain Physician2008;11:713-6. 